\section{Tropical Journal of Pathology and Microbiology}

\title{
The utility of fine-needle aspiration cytology in differentiating granulomatous mastitis and tuberculous mastitis
}

\author{
Sukumar C. ${ }^{1}$, Singh G. ${ }^{2 *}$, Kumar Yadav S. ${ }^{3}$, Jahan A. ${ }^{4}$, Singh S. ${ }^{5}$, Sarin N. \\ DOI: https://doi.org/10.17511/jopm.2021.i01.04 \\ ${ }^{\mathbf{1}}$ Challa Sukumar, DNB Resident, ${ }^{\mathbf{2 *}}$ Garima Singh, Specialist, ${ }^{\mathbf{3}}$ Shakti Kumar Yadav, Senior Resident, ${ }^{\mathbf{4}}$ Aarzoo Jahan, GDMO-II, ${ }^{\mathbf{5}}$ Sompal \\ Singh, Specialist, ${ }^{6}$ Namrata Sarin, Specialist and Head of the Department; all authors affiliated with the Department of Pathology, North \\ Delhi Municipal Corporation Medical College and Hindu Rao Hospital, Delhi, India.
}

Background: Tuberculous mastitis (TM) is a rare extrapulmonary presentation of tuberculosis accounting for less than $1 \%$ of all diseases of the breast in the industrialized world. Granulomatous Mastitis (GM) is an uncommon chronic inflammatory disease of the breast that almost always mimics cancer in young individuals, so it can be a diagnostic dilemma. Aims and objectives: The main aim of this study is to elucidate the utility of FNAC in differentiating granulomatous mastitis and tuberculous mastitis. Materials \& Methods: A retrospective observational study was conducted at the department of pathology, Hindu Rao Hospital, Delhi. Cytology database was revealed for a period of 4 years (2016-2019). The clinical details wherever available and cytological morphology of individual cases were noted and analysed. Results: In our study out of 20 cases 11 cases $(55 \%)$ were found to be granulomatous mastitis and the other 9 cases (45\%) were found to be tuberculous mastitis. All cases were of female patients only, with equal side distribution. In the cytological smears of GM, three $(27.3 \%)$ smears showed ductal epithelial cells, epithelioid cell granulomas were seen in $11(100 \%)$ cases and singly scattered epithelioid cells were seen in nine $(81.8 \%)$ cases. Caseous necrosis was observed only in one case $(9.09 \%)$ but necrotic material intermixed with degenerated neutrophils and apoptotic bodies were seen in four cases $(36.4 \%)$. Conclusion: FNAC can be an accurate method for differentiating tuberculous mastitis from granulomatous mastitis as per cytomorphological findings, along with confirmation by the demonstration of acid-fast bacilli and hence can help to decide the appropriate treatment protocols for such patients.

Keywords: Tuberculous Mastitis, granulomatous mastitis, Fine needle aspiration (FNAC), Acid-fast bacillus (AFB), Epithelioid cell granulomas

Corresponding Author

Garima Singh, Specialist, Department of Pathology, North Delhi Municipal Corporation Medical College and Hindu Rao Hospital, Delhi, India. Email: drgarimasingh2011@gmail.com
How to Cite this Article

To Browse

Sukumar C, Singh G, Yadav SK, Jahan A, Singh S, Sarin $N$. The utility of fine-needle aspiration cytology in differentiating granulomatous mastitis and tuberculous mastitis. Trop J Pathol Microbiol. $2021 ; 7(1): 26-32$.

Available From

https://pathology.medresearch.in/index.php/jopm/ar

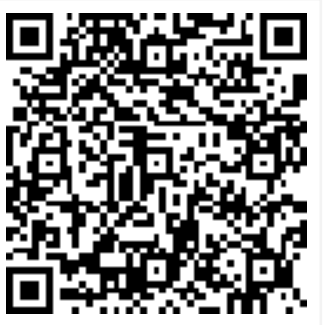
ticle/view/500
Manuscript Received 2020-12-12

Conflict of Interest No
Review Round 1 2020-12-22

Funding Nil
Review Round 2 2020-12-31

Ethical Approval Yes
Review Round 3

Plagiarism X-checker $9 \%$
Accepted 2021-01-27

(c) 2021 by Challa Sukumar, Garima Singh, Shakti Kumar Yadav, Aarzoo Jahan, Sompal Singh, Namrata Sarin and Published by Siddharth Health Research and Social Welfare Society. This is an Open Access article licensed under a Creative Commons Attribution 4.0 International License https://creativecommons.org/licenses/by/4.0/ unported [CC BY 4.0].
Note 


\section{Introduction}

Granulomatous Mastitis (GM) is an extremely rare chronic inflammatory disease of the breast that almost always mimics cancer in young individuals [1]. Aetiologically GM is divided into specific and non-specific types. The term "specific GM" is used when the aetiological factor can be identified [1]. These may be categorised as infectious causes like Mycobacterium tuberculosis.

GM should be distinguished from tubercular mastitis because they have overlapping clinical, radiological and cytological features and also because their treatment differs considerably. The pathogenesis of granulomatous mastitis is unclear, as its relation to the duct ectasia or periductal mastitis group of conditions, in which a granulomatous inflammatory component may be present [2].

Tuberculosis is the most widespread and persistent human infections in the world which can involve any organ. But tuberculosis of the breast is a rare form of tuberculosis $[3,4]$. Among all breast lesions, the incidence of tubercular mastitis is less than $0.1 \%$ in Western countries whereas in tuberculosis endemic regions, such as India and Africa the incidence reaches up to $3 \%[5,6]$. It commonly affects young women in the reproductive age group particularly during the lactational period. It is also reported in prepubescent males and elderly women [7]. The breast tissue is remarkably resistant to tuberculosis [8].

The disease most commonly presents as a lump in the central or upper-outer quadrant of the breast, however multiple lumps appear less frequently. Because of its nonspecific features mammography has a limited role in the diagnosis. It is a diagnostic challenge as it closely mimics carcinoma of the breast and pyogenic inflammatory disease. When other routine laboratory investigations do not help to conclude tubercular mastitis, Fine needle aspiration cytology (FNAC) is a very essential diagnostic tool. We have reviewed 20 cases of tuberculosis of the breast here, which were rare manifestations of a common disease in a country like India.

\section{Materials and methods}

The present study is a retrospective observational study was conducted at the department of pathology of a tertiary care hospital, Delhi.
About four-year (2016-2019) data of the cytopathology section was scrutinized for identification of breast FNAs which were either reported as granulomatous mastitis (Nontuberculous) and tuberculous mastitis. All the consecutive cases were included in the study. Cases with scanty cellularity were excluded from the study. Fine needle aspiration has been obtained using a 22-gauge needle connected to $10 \mathrm{ml}$ of disposable syringe.

Air-dried smears were stained using May-GrunwaldGiemsa (MGG) and also slides were subsequently stained by ZN stain for detection of acid-fast bacilli. Clinical details including patient age, gender, the family history of tuberculosis, presence of sinus and axillary lymphadenopathy were noted. Cytological parameters like epithelioid cell granuloma, histiocytes, giant cells, necrosis, ductal epithelial cells and neutrophils were evaluated in all the cases. The numerical data were summarized in the form of mean and standard deviation.

The categorical data were summarized in form of a percentage of various categories. To assess the significance of the age difference, the Student's ttest was used and for the duration of symptoms and tumour volume, the Mann-Whitney test was used. To assess the significance of the difference in proportions of clinical features and cytomorphological features, a z-test was used. A pvalue of $<0.05$ was taken as statistically significant.

\section{Results}

A total number of 20 cases were retrieved. The clinical presentation and cytological features of those cases are summarized in Table $1 \& 2$. Clinical details including presence/absence of a breast mass (solitary or multiple), skin changes (sinus tracts, ulcers, skin thickening, or skin discolouration), the presence of palpable axillary lymphadenopathy, and nipple retraction were recorded for the patient wherever available. The presence of mastalgia, nipple discharge, and constitutional symptoms such as fever or weight loss were also recorded from the patient archives. All cases presented with breast swelling, the lower outer quadrant was the most frequent quadrant to be affected. Right and left breast involvement was equally distributed. There was no case of bilateral involvement in this series. All cases were of female patients only. The mean age of GM patients was 26.81 years +/- 5.546 and of TM patients were 32.11 years +/- 10.067. 
The median duration of symptoms was 3 months (range 1 to 24 months) in GM patients and 7 months (range 2 to 60 months) in TM patients. (Table 1). A history of pulmonary TB was found in six $(30 \%)$ patients and 8 patients were lactating mothers.

Table.1 Clinical findings in GM \& TM

\begin{tabular}{|l|l|l|c|}
\hline \multicolumn{1}{|c|}{ Clinical Findings } & \multicolumn{1}{|c|}{ GM } & \multicolumn{1}{c|}{ TM } & $\begin{array}{c}\text { p- } \\
\text { value }\end{array}$ \\
\hline $\begin{array}{l}\text { Age - Mean +/- Standard deviation } \\
\text { (years) }\end{array}$ & $\begin{array}{l}26.81+/- \\
5.546\end{array}$ & $\begin{array}{l}32.11+/- \\
10.067\end{array}$ & $0.183 *$ \\
\hline $\begin{array}{l}\text { Duration of symptom-Median, Range } \\
\text { (months) }\end{array}$ & $3(1-24)$ & $7(2-60)$ & $0.210 \$$ \\
\hline Mean volume- Median, Range (cm3) & $4(0.5-40)$ & $1.5(0.5-48)$ & $0.360 \$$ \\
\hline Tenderness & $5(45.5 \%)$ & $2(22.2 \%)$ & $0.280 \#$ \\
\hline Discharging sinus & $3(27.3 \%)$ & $1(11.1 \%)$ & $0.368 \#$ \\
\hline Lymphadenopathy & $1(9.1 \%)$ & $4(44.4 \%)$ & $0.068 \#$ \\
\hline
\end{tabular}

\section{*- student's t-test, \$- Mann-whitney test, \#- z- test}

On palpation, the majority had a firm to hard, illdefined lump with tenderness present in five patients of GM and two TM patients. Four patients had multiple discharging sinuses in the breast. Lymphadenopathy was more commonly present in TM patients with a p-value of 0.068 . A definitive diagnosis of breast tuberculosis was established on FNAC in nine cases (45\%) based on morphologic features and presence of AFB, while the diagnosis of the remaining eleven cases (55\%) was suggested on FNAC smears as granulomatous mastitis and advised for PCR to rule out tuberculosis.

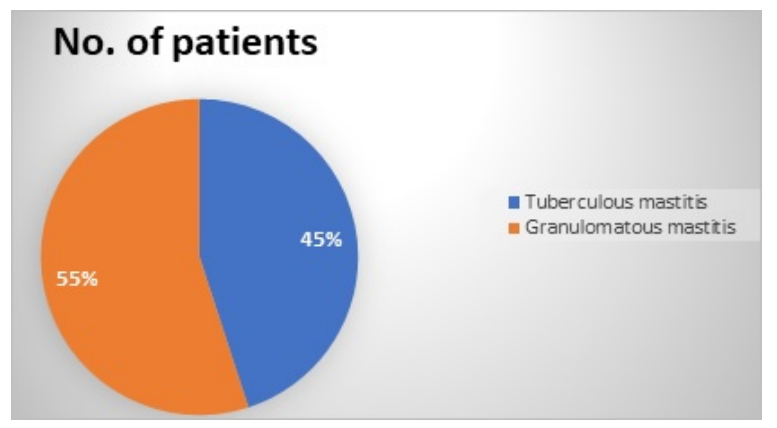

Fig-1: Incidence of granulomatous mastitis and Tuberculous mastitis.

In the cytological smears of eleven GM patients, three (27.3\%) smears showed ductal epithelial cells, many of them exhibiting reactive atypia. Epithelioid cell granulomas were seen in 11 (100\%) cases and singly scattered epithelioid cells were seen in nine $(81.8 \%)$ cases.
Caseous necrosis was observed only in one case $(9.09 \%)$ but necrotic material intermixed with degenerated neutrophils and apoptotic bodies were seen in four cases (36.4\%). Giant cells, mostly foreign body type, were seen in four (36.4\%) of the cases. Background inflammation was composed of neutrophils along with few lymphocytes.

Table 2: Cytological findings in GM \& TM

\begin{tabular}{|l|l|l|l|}
\hline Cytological Findings & \multicolumn{1}{|c|}{$\begin{array}{c}\text { GM Total No.of } \\
\text { cases 11 }\end{array}$} & $\begin{array}{c}\text { TM Total No. of } \\
\text { cases 9 }\end{array}$ & \multicolumn{1}{|c|}{$\begin{array}{c}\text { p-value (z- } \\
\text { test) }\end{array}$} \\
\hline Ductal epithelial cells & $3(27.3 \%)$ & $2(22.2 \%)$ & 0.794 \\
\hline Epithelioid cells & $9(81.8 \%)$ & $6(66.7 \%)$ & 0.435 \\
\hline $\begin{array}{l}\text { Epithelioid cell } \\
\text { granulomas }\end{array}$ & $11(100 \%)$ & $3(33.3 \%)$ & 0.001 \\
\hline Caseous necrosis & $1(9.09 \%)$ & $3(33.3 \%)$ & 0.177 \\
\hline Inflammatory necrosis & $4(36.4 \%)$ & $2(22.2 \%)$ & 0.490 \\
\hline Foreign body giant Cells & $4(36.4 \%)$ & $0(0 \%)$ & 0.043 \\
\hline Langhans giant Cells & $2(18.2 \%)$ & $5(55.6 \%)$ & 0.082 \\
\hline $\begin{array}{l}\text { Mixed (Neutrophils+ } \\
\text { Lymphocytes) }\end{array}$ & $1(9.09 \%)$ & $4(44.4 \%)$ & 0.069 \\
\hline
\end{tabular}

In the cytological smears of TM, two (22.2\%) cases had ductal epithelial cells. Epithelioid cells and giant cells, mainly Langhans type were present in five cases $(55.6 \%)$. Epithelioid cell granulomas were seen in three cases (33.3\%), which shows plump histiocytes either singly or in clusters. Caseous necrosis was seen in three (33.3\%) cases. Background inflammation was composed of neutrophils along with few lymphocytes in four cases $(44.4 \%)$.

After comparing the cytomorphological details between the two groups i.e GM and TM, it was found that the presence of epithelioid cell granulomas and foreign body giant cells were significantly more common in GM cytosmears as compared to TM with a p-value of 0.001 and 0.045 respectively.

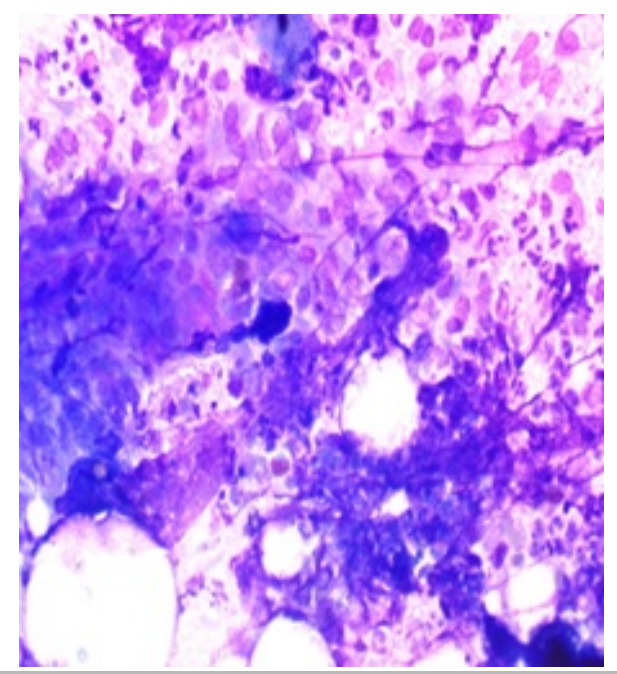



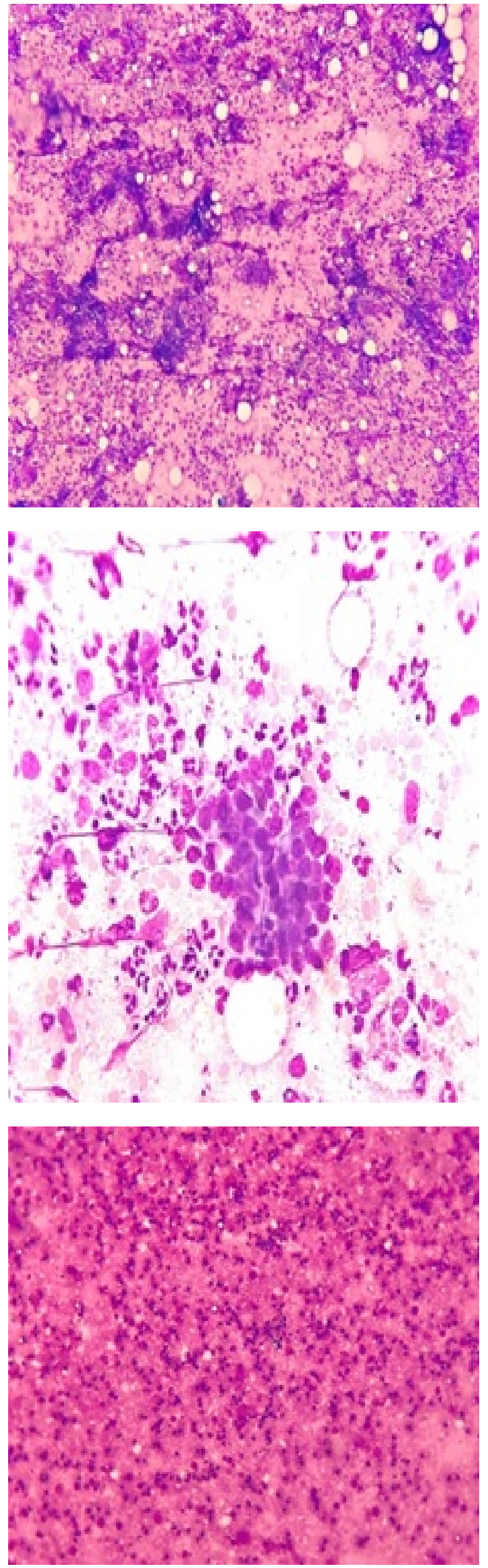
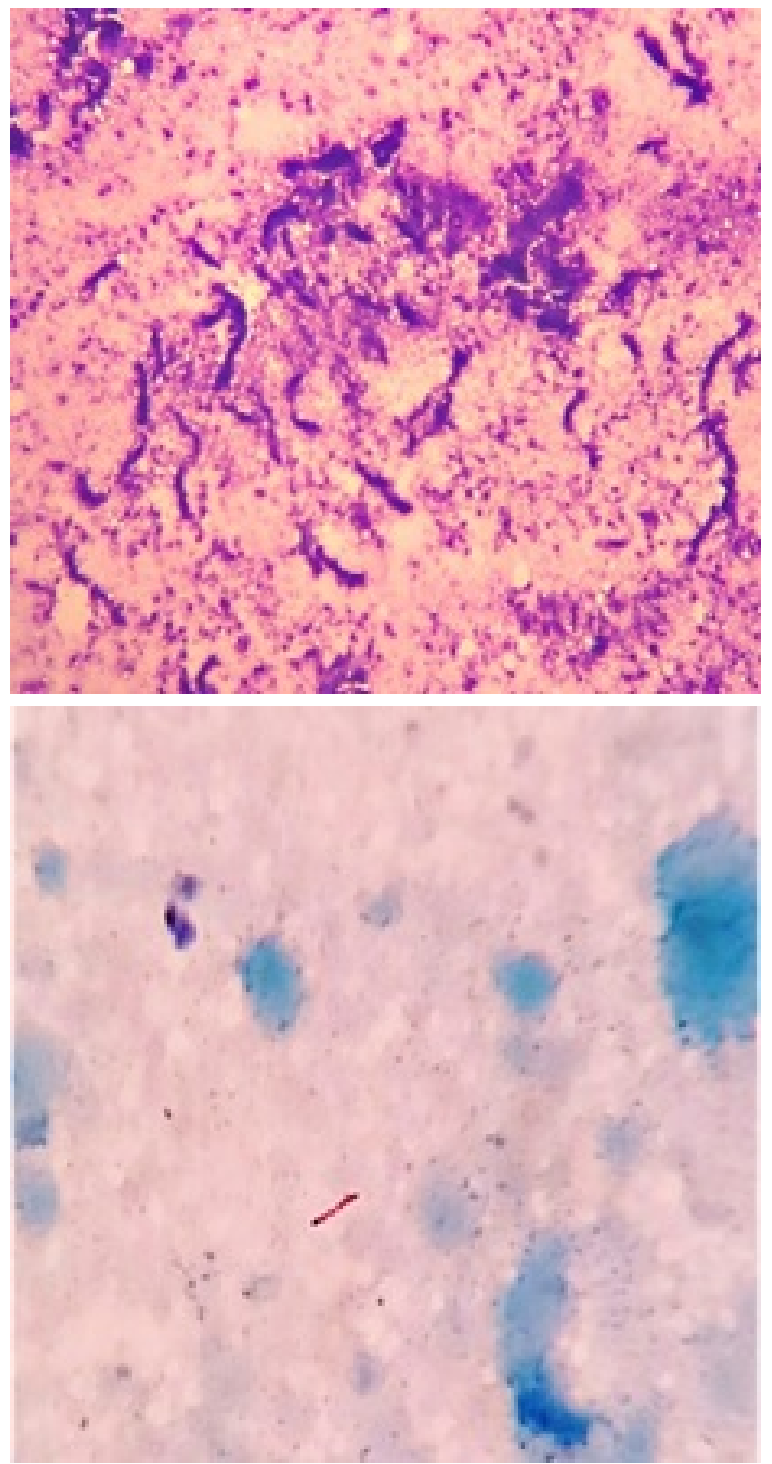

\section{Fig-2: Photomicrography of Cytological findings}

Photomicrography showing: a) Epithelioid cells singly scattered along with ill-formed epithelioid granulomas admixed with neutrophils (MGG $\times 40$ ); b\&c) Ductal epithelial cells along with mixed inflammatory cells (MGG $\mathrm{x} 4$ and $\mathrm{x} 40$ ); d) Inflammatory necrosis admixed with neutrophils and apoptotic cells (MGG $\times 40$ ); e) Necrotic background (MGG x4); f) Positive AFB (Ziehl-Neelsen, x100)

\section{Discussion}

Tuberculous mastitis (TM) is an infrequent disease but in developing countries like India it is one of the common causes of granulomatous mastitis. Tuberculous mastitis is a rare disorder that is often mistaken for carcinoma of the breast and pyogenic inflammatory disease clinically and radiologically, hence accurate diagnosis is essential to avoid unnecessary mastectomies [9]. 
Tuberculosis in the breast is an extremely rare disease, because mostly organs or tissues like the spleen, breast and skeletal muscle are more resistant to the infection, making the survival and multiplication of the tubercle bacilli difficult. In India, the incidence of tuberculous mastitis has been reported to be between $1-4.5 \%$ [10]. Sir Astley Cooper reported the first case of breast tuberculosis and he described it as "scrofulous swelling of the bosom [11].

Tuberculous mastitis is more commonly seen in females of the reproductive age group particularly during the lactational period $[12,13,14]$. Because during lactation the mammary gland is more vascular and predisposed to trauma [15]. In our study age of patients ranges from $19 \mathrm{yrs}$ to $50 \mathrm{yrs}$ (mean age $28.05+/-5.05$ ) and 8 patients were in lactation (40\%). Both breasts are involved with equal frequency. However bilateral disease is very rare which occurs in $3 \%$ of patients [14]. Our study shows right-sided involvement in 10 patients $(50 \%)$, while left breast involvement was found in the other 10 patients (50\%). There was no case of bilateral involvement in this series. The duration of symptoms varies from a few months to several years, but in most cases it is less than a year.

Granulomatous mastitis (GM) is an uncommon inflammatory lesion of the breast which is due to various etiologies like tuberculosis, fungal infections, connective tissue disorders, fat necrosis and sarcoidosis. If no attributable cause is detected then it is termed idiopathic which was first described by Kessler and Wolloch in 1972 [16]. Tuberculous involvement of the breast can occur in two forms. The primary form is through infection of the breast by abrasions or through the openings of ducts in the nipple. The secondary form is through retrograde lymphatic flow in the axillary lymph nodes or may be due to the direct spread of the infection from intra-thoracic foci.

The most common presenting symptom is the breast lump. Multiple lumps are less frequent. The classical presentation of matted nodes, multiple sinuses, ulcers and the breast mass is less common, which makes clinical diagnosis difficult. Other uncommon presentation can be purulent discharge from the nipple, a typical tuberculous ulcer or a fluctuant swelling which if accidentally incised produce discharging ulcer [17]. In our study five patients $(25 \%)$ had associated signs of inflammation in the form of redness and raised temperature.
Five $(25 \%)$ had multiple discharging sinuses in the breast.

In tuberculous mastitis the breast lump is usually irregular, ill-defined, hard which is indistinguishable from carcinoma. Pain is present most frequently. The involvement of areola and nipple are rare in tuberculosis. Fixation to the skin is seen frequently and often regional lymph nodes are enlarged. On radiographic examination, lung lesions (active or healed) are rare. Mammography findings are not useful, since they are indistinguishable from carcinoma.

McKeon et al [18] classified breast tuberculosis into the following categories: (a) acute miliary type very rare, which is due to bloodborne infection in military tuberculosis; (b) nodular type - the most common type, which presents as a localized lump with or without sinuses in any quadrants of the breast; (c) disseminated type - which involves the entire breast with multiple sinuses; (d) sclerosing type - with minimal caseation and extensive hyalinization of the stroma, along with shrinkage of the breast tissue with late sinus formation and early skin retraction; clinically this type is indistinguishable from carcinoma; and (e) tuberculous mastitis obliterans - a rare form due to intraductal in section with fibrosis and obliteration of the ductal system; sinus formation is infrequent.

Cytology of the GM is characterised by the presence of non-caseating epithelioid granulomas, multinucleated giant cells with or without necrosis [19]. These cytological findings overlap with that of TM. The presence of epithelioid granulomas, along with caseous necrotic material, and Langhans type of giant cells are considered typical for a TM [20].

In our study, following the comparative analysis of cytomorphological details of GM and TM groups, we found a statistically significant association of the presence of epithelioid cell granulomas and foreign body giant cells well on GM smear as compared to TM smears. Also, the presence of Langhans giant cells, mixed inflammatory cells and lymphadenopathy were more common in TM patients as compared to GM patients, however, the difference was not statistically significant.

Not all cases of Tuberculous mastitis are positive for acid-fast bacilli and not all cases have a caseous necrotic background. Demonstration of $A F B$ in cytology smear of TM requires the bacterial load to be 10,000 to $1,00,000 / \mathrm{ml}$ of the material and culture isolates organism only in $25 \%$ of the cases 
[21]. The gold standard diagnosis of Tuberculous mastitis is a bacteriological culture or demonstration of acid-fast bacilli by Ziehl Neelsen (ZN) stain.

The optimal treatment of $\mathrm{GM}$ is controversial. In most cases, steroid therapy has a good response. Wide surgical excision is advised in complicated cases, while TM requires antitubercular therapy for six months like pulmonary tuberculosis [22]. A flareup of infection can occur in cases of TM as GM is treated with steroid or methotrexate which can be harmful to the patient.

Hence, we recommend in cases of GM, tubercular aetiology must be ruled out with a repeat FNAC. All patients should receive adequate anti-tubercular treatment (ATT). After completion of ATT the residual lumps are be excised via segmental or sector mastectomy. Radical mastectomy is avoided until and unless if there is a co-existing malignancy.

\section{Limitations}

The limitations of the present study are that all the cases of GM which are diagnosed on cytology were not followed up for histopathological diagnosis which is the gold standard test for GM. All the cases of TM which were diagnosed based on ZN staining are the less sensitive test. PCR test which is a sensitive and specific test for TM could not be performed due to financial constraints.

\section{Conclusion}

Although granulomas may be seen in both granulomatous mastitis and tuberculous mastitis, there are cytomorphological differences between the two entities. We found that well defined epithelioid cell granulomas are more common in granulomatous mastitis. Moreover, foreign body giant cells were seen in a fair number of granulomatous mastitis cases. Whereas, Langhans giant cells were more common in tuberculous mastitis.

\section{What does the study add to the existing knowledge?}

Keeping in mind the difference in treatment of these two entities, the cytomorphological differences as suggested by this study may help decide the appropriate treatment protocols of such patients.

\section{Authors' contribution}

01. Dr Challa Sukumar - Data acquisition, manuscript preparation

02. Dr Garima Singh - Data acquisition, manuscript preparation, Literature Search

03. Dr Shakti Kumar Yadav - Statistical analysis, manuscript editing

04. Dr Aarzoo Jahan - Data analysis, manuscript editing

05. Dr Sompal Singh (Guarantor) - Concept and design, Data analysis

06. Dr Namrata Sarin - Concept and design

\section{Reference}

01. Altintoprak F, Kivilcim T, Ozkan OV. Aetiology of idiopathic granulomatous mastitis. World J Clin Cases. 2014;2(12)852-58. doi: $10.12998 /$ wjcc.v2.i12.852 [Crossref]

02. Going JJ, Anderson TJ, Wilkinson S, Chetty U. Granulomatous lobular mastitis. J Clin Pathol. $1987 ; 40 ; 535-40$.

doi: $10.1136 /$ jcp.40.5.535 [Crossref]

03. Kalac N, Ozkan B, Bayiz H, Dursun AB, Demirag F. Breast tuberculosis. Breast. 2002;11;346-49. doi: $\quad 10.1007 / \mathrm{s} 12262-015-1272-1 \quad$ [Crossref]

04. Kakkar S, Kapila K, Singh MK, Verma K. Tuberculosis of the breast- A cytomorphologic study. Ada Cytol. 2000;44;292-96.

doi: $10.1159 / 000328467$ [Crossref]

05. Luh SP, Chang KJ, Cheng JH, Hsu JD, Huang CS. Surgical treatment for primary mammary tuberculosis - report of three octogenarian cases and review of literature. Breast Journal. $2008 ; 14 ; 311-2$.

doi: $10.1111 / \mathrm{j} .1524-4741.2008 .00584 . x \quad$ [Crossref]

06. Maroulis I, Spyropoulos C, Zolota V, Tzorakoleftherakis E. Mammary tuberculosis mimicking breast cancer- a case report. Journal of Medicine Case Reports. 2008;2;34.

doi: 10.1186/1752-1947-2-34 [Crossref] 
07. Gupta A, Gupta M, Gupta J. Unusual case of bilateral tubercular mastitis. Cureus. 2017 Jun;9(6).

[Crossref]

08. Mukerjee P, George M, Maheshwari HB, Rao CP. Tuberculosis of the breast. J Indian Med Assoc. $1974 ; 62 ; 410-12$.

[Crossref]

09. Seo HRN, Na KY, Yim HE, KimTH, Kang DK, Oh $\mathrm{KK}$, et al. Differential Diagnosis in Idiopathic Granulomatous Mastitis and Tuberculous Mastitis. J Breast Cancer. 2012;15(1)111-8. [Crossref]

10. Aggarwal V, Bhargava P. Breast tuberculosis-a case report. J Indian Med Assoc. 2008 Jan;106(1)38-40.

[Crossref]

11. Cooper A. Illustration of the Diseases of the Breast- Part I, Longmans, Orme, London. Brown \& Green. 1829.

[Crossref]

12. Shinde SR, Chandowarkar RY, Deshmukh SP. Tuberculosis of the breast masquerading as carcinoma- A study of 100 patients. World J Surg. $1995 ; 19 ; 379-81$.

[Crossref]

13. Hamit HF, Ragsdale TH. Mammary tuberculosis. J R Soc Med. 1982;75;764-5.

[Crossref]

14. Banerjee S N, Ananthakrishnan N, Mehta R B, Prakash S. Tuberculous mastitis- A continuing problem. World J Surg. 1987;11;105-9.

[Crossref]

15. Tewari M, Shukla HS. Breast tuberculosisdiagnosis, clinical features \& management. Indian J Med Res. 2005 Aug;122(2)103-110.

[Crossref]
16. Kessler E, Wolloch Y. Granulomatous mastitis- a lesion clinically simulating carcinoma. Am J Clin Pathol. 1972;58(6)6.

[Crossref]

17. Al Soub $H$, Chacko K. Tuberculous mastitis- a rare disease. $\mathrm{Br}$ J Clin Pract. 1996.

Jan-Feb;50(1)50-51 [Crossref]

18. McKEOWN KC, Wilkinson KW. Tuberculous disease of the breast. $\mathrm{Br} \mathrm{J}$ Surg. 1952 Mar;39(157)420-429.

[Crossref]

19. Helal TE, Shash LS, Saad El-Din SA, Saber SM. Idiopathic granulomatous mastitis- cytologic and histologic study of 65 Egyptian patients. Acta Cytol. 2016;60(5)438-44.

[Crossref]

20. Elsiddig KE, Khalil EA, Elhag IA, Elsafi ME. Granulomatous mammary disease- ten years' experience with fine needle aspiration cytology. Int J Tuberc Lung Dis. 2003;7(4)365-69.

[Crossref]

21. Kishore B, Khare P, Gupta RJ, Bisht SP. Fine needle aspiration cytology in the diagnosis of inflammatory lesions of the breast with emphasis on tuberculous mastitis. J Cytol. 2007;24(3)155-56.

[Crossref]

22. Kiyak G, Dumlu EG, Kilinc I, Tokaç M, Akbaba S, Gurer A. Management of idiopathic granulomatous mastitis- dilemmas in diagnosis and treatment. BMC Surg. 2014;4(4)66.

[Crossref] 